\title{
Pengaruh Aliran Kas Bebas dan Keputusan Pendanaan Terhadap Nilai Pemegang Saham dengan Set Kesempatan Investasi dan Dividen Sebagai Variabel Moderasi
}

\author{
Metha Arieska dan Barbara Gunawan \\ Universitas Muhammadiyah Yogyakarta \\ Email: metha.rieska@yahoo.co.id, barbaragunawan@yahoo.co.id
}

\begin{abstract}
ABSTRAK
Penelitian ini menganalisis pengaruh aliran kas bebas dan keputusan pendanaan terhadap nilai pemegang saham dengan set kesempatan investasi dan dividen sebagai variabel moderasi. Sampel penelitian ini adalah 23 perusahaan manufaktur yang terdaftar di Bursa Efek Indonesia (BEI) dari tahun 2005-2009. Teknik analisis yang digunakan adalah moderated regression analysis (MRA) dengan menggunakan program SPSS 15. Penelitian ini menggunakan variabel dependen nilai pemegang saham, dan variabel independen adalah aliran kas bebas dan keputusan pendanaan. Variabel moderasi adalah set kesempatan investasi dan dividen. Hasil dari penelitian ini bahwa pada pengujian secara serentak (Uji F), variabel aliran kas bebas, keputusan pendanaan, set kesempatan investasi, dividen, moderasi aliran kas bebas dengan set kesempatan investasi, moderasi aliran kas bebas dengan dividen, moderasi keputusan pendanaan dengan set kesempatan investasi, moderasi keputusan pendanaan dengan dividen dan ukuran perusahaan berpengaruh positif signifikan terhadap nilai pemegang saham. Pada pengujian secara parsial (Uji T), variabel moderasi aliran kas bebas dengan set kesempatan investasi, moderasi aliran kas bebas dengan dividen, moderasi keputusan pendanaan dengan set kesempatan investasi menunjukkan hasil positif signifikan, tetapi variabel keputusan pendanaan dan moderasi keputusan pendanaan dengan dividen tidak menunjukkan hasil yang signifikan.
\end{abstract}

Kata kunci: Aliran kas bebas, keputusan pendanaan, set kesempatan investasi, dividen nilai pemegang saham.

\begin{abstract}
This research was conducted to analyze the influence of free cash flow and funding decisions on shareholder value with a set of investment opportunities and dividend as a moderating variable. The sample in this study is 23 companies listed in Indonesia Stock Exchange (IDX) of the years 2005-2009. The analysis technique used is moderated regression analysis (MRA) using the program SPSS 15. This study used the dependent variable shareholder value, while the independent variable is free cash flow and financing decisions as well as moderating variable is the set of investment opportunities and dividend. The results of this study indicate that the simultaneous testing (Test F), variable-free cash flow, financing decisions, investment opportunity set, dividends, free cash flow moderation with a set of investment opportunities, free cash flow moderation with dividends, moderation with a set of funding decisions investment opportunities, funding decisions moderation with dividends and company size has a significant positive effect on shareholder value. In a partial test (Test T), free cash flow moderating variables with the investment opportunity set, moderation of free cash flow to dividends, moderation funding decision with the investment opportunity set showed significant positive results, but the variable funding decisions and funding decisions moderation with a dividend does not show significant results.
\end{abstract}

Keywords: Free cash flow, financing decisions, investment opportunity set, dividend, shareholder value. 


\section{PENDAHULUAN}

Tujuan utama perusahaan adalah meningkatkan nilai perusahaan melalui peningkatan kemakmuran politik para pemegang saham. Pemegang saham, kreditor dan manajer adalah pihak-pihak yang memiliki perbedaan kepentingan dan perspektif berkenaan dengan perusahaan. Pemegang saham akan cenderung memaksimalkan nilai saham dan memaksa manajer untuk bertindak sesuai dengan kepentingan mereka melalui pengawasan yang mereka lakukan. Kreditor di sisi lain cenderung akan berusaha melindungi dana yang sudah mereka investasikan dalam perusahaan dengan jaminan dan kebijakan pengawasan yang ketat pula. Manajer juga memiliki dorongan untuk mengejar kepentingan pribadi mereka. Bahkan tidak tertutup kemungkinan para manajer melakukan investasi walaupun investasi tersebut tidak dapat memaksimalkan nilai pemegang saham. Konflik kepentingan antara pemegang saham pemegang saham dengan manajer dapat timbul jika manajer bertindak untuk kepentingannya sendiri demi mendapatkan keuntungan yang sebesar-besarnya tanpa memperhatikan kepentingan para pemegang saham (Wardani dan Siregar 2009).

Masalah keagenan dapat disebabkan oleh keberadaan aliran kas bebas. Hal tersebut dikarenakan adanya perbedaan kepentingan antara pemegang saham dan manajer. Pemegang saham menginginkan sisa dana tersebut dibagikan untuk meningkatkan kesejahteraannya sementara manajer berkeinginan dana yang ada digunakan untuk memperbesar perusahaan melebihi ukuran optimalnya sehingga mereka tetap melakukan investasi meskipun investasi tersebut memberikan net present value negatif. Bagi pemegang saham, keputusan tersebut dinilai sebagai keputusan yang tidak berpihak kepada pemegang saham.

Jensen (1986) dalam Wardani dan Siregar (2009) mendefinisikan aliran kas bebas sebagai kelebihan kas yang diperlukan untuk mendanai semua proyek yang memiliki nilai bersih sekarang positif. Aliran kas bebas mencerminkan keleluasaan perusahaan dalam melakukan investasi tambahan, melunasi hutang, membeli saham treasury atau menambah likuiditas, sehingga aliran kas bebas yang tinggi mengindikasikan kinerja perusahaan yang tinggi. Kinerja dari perusahaan yang tinggi akan meningkatkan nilai pemegang saham yang diwujudkan dalam bentuk return yang tinggi melalui dividen, harga saham, atau laba ditahan untuk diinvestasikan di masa depan. Jadi jika aliran kas bebas tinggi, maka nilai pemegang saham juga akan tinggi.
Menurut Wahidawati (2002), peningkatan pendanaan melalui utang merupakan salah satu alternatif untuk mengurangi biaya keagenan. Hutang dapat mengendalikan manajer untuk mengurangi tindakan perquisites dan kinerja perusahaan menjadi lebih efisien sehingga penilaian investor terhadap perusahaan akan meningkat.

Jensen (1986) dalam Wardani dan Siregar (2009) menyatakan berdasarkan prediksi, harga saham akan meningkat jika perusahaan membayar atau berjanji untuk membayar kelebihan kas yang dimiliki kepada pemegang saham. Dengan kata lain, peningkatan pembayaran dividen dalam bentuk dividen kas akan menghasilkan respon positif pada harga saham dalam jangka pendek.

Menurut Fama dan French (1998) dalam Wijaya dkk. (2010)Investasi yang dihasilkan dari leverage memiliki informasi yang positif tentang perusahaan di masa yang akan datang, selanjutnya berdampak positif terhadap nilai perusahaan. Perusahaan yang mempunyai dana yang besar (berasal dari leverage) dengan set kesempatan investasi yang tinggi, maka manajernya akan menggunakan dana tersebut untuk membiayai proyek dengan nilai bersih sekarang positif sehingga akan meningkatkan nilai pemegang saham

Financial leverage mempunyai pengaruh yang positif terhadap dividend payout ratio. Perusahaan dengan prospek yang baik, cenderung akan mempergunakan hutang sebagai alternatif untuk memenuhi kebutuhan pembayaran dividen dalam jangka pendek, apabila perusahaan tidak mempunyai dana internal untuk memenuhi dana tersebut. Sehingga jika perusahaan menggunakan hutang sebagai alternatif kebutuhan untuk pembayaran dividen maka nilai perusahaan akan meningkat (Baskin 1989) dan (Adedeji 1998) dalam (Haruman 2008)

Masalah dalam penelitian ini adalah apakah aliran kas bebas dan keputusan pendanaan, apakah set kesempatan investasi dan dividen dapat memoderasi pengaruh positif aliran kas bebas dengan nilai pemegang saham serta apakah set kesempatan investasi dapat memoderasi pengaruh positif keputusan pendanaan dengan nilai pemegang saham. Tujuan dalam penelitian ini untuk menguji apakah aliran kas bebas dan keputusan pendanaan, set kesempatan investasi dan dividen dapat memoderasi pengaruh positif aliran kas bebas dengan nilai pemegang saham serta apakah set kesempatan investasi dapat memoderasi pengaruh positif keputusan pendanaan dengan nilai pemegang saham. 
Perspektif konflik antara pemegang saham dengan manajer dapat dijelaskan dalam kerangka hubungan keagenan. Suatu hubungan keagenan adalah hubungn kontraktual antara pemegang saham sebagai prinsipal yang member amanah dan manajer sebagai agen yang menjalankan amanah. Menurut Kaaro (2002) dalam Wardani dan Siregar (2009), Teori Sinyal mengasumsikan bahwa manajer pada perusahaan yang berkualitas tinggi memiliki insentif untuk meyakinkan investor bahwa perusahaan seharusnya menetapkan penilaian yang lebih tinggi berdasarkan pengetahuan manajer mengenai prospek yang baik bagi perusahaan atau peluang investasinya. Menurut Myers dan Majluf (1984 dalam Wardani dan Siregar (2009). Manajer memilih menggunakan dananya untuk mendanai investasi daripada mengeluarkan biaya yang besar untuk pembagian dividen kepada para pemegang saham sebagai sinyal informasi bagi outside shareholders. Dengan kata lain, manajer memilih untuk memaksimalkan kekayaan current shareholders daripada mengharapkan kekayaan outsiders shareholders dan potential shareholders yang hanya tertarik pada jumlah dividen yang dibagikan Oleh karena itu dapat disimpulkan bahwa peluang investasi juga dapat dijadikan sinyal mengenai prospek perusahaan bagi current shareholders.

\section{ALIRAN KAS BEBAS}

Salah satu tujuan perusahaan adalah memaksimalkan nilai pemegang saham. Nilai pemegang saham merupakan nilai ekuitas yang menjadi bagian dari nilai perusahaan. Nilai pemegang saham merupakan nilai perusahaan dikurangi dengan hutang. Penman (2004) dalam Tarjo (2005) menyatakan bahwa salah satu tujuan perusahaan adalah memaksimalkan kekayaan pemegang saham melalui dividen dan meningkatkan harga saham. Ross et al. (2004) dalam Wardani dan Siregar (2009) menyatakan bahwa aliran kas bebas merupakan kas perusahaan yang dapat didistribusikan kepada pemegang saham yang tidak digunakan untuk modal kerja atau investasi pada aset tetap. Brown (1996) dalam Norpratiwi (2005) mendefinisikan aliran kas bebas sebagai aliran kas yang dihasilkan kembali kepada pemegang saham tanpa mempengaruhi tingkat pertumbuhan perusahaan saat ini. Menurut Jensen (1986) dalam Faisal (2004) aliran kas bebas merupakan kelebihan yang diperlukan untuk mendanai semua proyek yang mempunyai net present value positif setelah membagi deviden. Semakin besar arus kas yang ada, semakin besar fleksibilitas aliran kas bebas tersebut.
Oleh karena itu pengertian aliran kas adalah adanya dana yang berlebih, yang seharusnya didistribusikan kepada para pemegang saham, dan kepeutusan tersebut dipengaruhi oleh kebijakan manajemen. Kas biasanya menimbulkan konflik kepentingan antara manajer dan pemegang saham. Manajer lebih menginginkan dana tersebut diinvestasikan lagi pada proyek-proyek yang dapat menghasilkan keuntungan karena alternatif ini akan meningkatkan insentif yang diterimanya.

Aliran kas bebas mencerminkan keleluasaan perusahaan dalam melakukan investasi tambahan, melunasi hutang, membeli saham treasury atau menambah likuiditas. Sehingga aliran kas bebas yang tinggi mengindikasikan kinerja perusahaan yang tinggi. Kinerja dari perusahaan yang tinggi akan meningkatkan nilai pemegang saham yang diwujudkan dalam bentuk return yang tinggi melalui dividen, harga saham, atau laba ditahan untuk diinvestasikan di masa depan

\section{SET KESEMPATAN INVESTASI}

Keputusan pendanaan berkaitan dengan pemilihan sumber dana, baik berasal dari internal perusahaan maupun eksternal perusahaan, akan sangat mempengaruhi perusahaan. Sumber dana yang berasal dari sumber internal perusahaan adalah laba ditahan dan depresiasi, sedangkan dana yang berasal dari eksternal perusahaan adalah dana yang berasal dari kreditur dan peserta atau pengambil bagian di dalam perusahaan. Apabila perusahaan memenuhi kebutuhan pendanaan dari penerbitan saham baru dikatakan perusahaan itu melakukan pendanaan atau pembelanjaan modal sendiri. Dalam melaksanakan fungsi pemenuhan kebutuhan dana dan fungsi pendanaan, manajer keuangan selalu mencari alternatif-alternatif sumber dana untuk kemudian dianalisa untuk memutuskan langkah terbaik dalam pendanaan perusahaan.

Hartono (1999) dalam Wardani dan Siregar (2009) mendefinisikan set kesempatan investasi adalah tersedianya alternatif investasi di masa yang akan datang bagi perusahaan Set kesempatan investasi dapat didefinisikan sebagai kombinasi antara aktiva riil (asset in place) dengan alternatif investasi di masa yang akan datang yang memiliki nilai bersih sekarang positif. Set kesempatan investasi merupakan variabel yang tidak dapat diobservasi (variabel laten), sehingga diperlakukan proksi (Hartono 2002). Menurut Kallapur dan Trombley (2000), Pagalung (2003) dalam Wardani dan Siregar (2009), proksi set kesempatan investasi dapat diklasifikasikan ke dalam empat tipe 


\section{Proksi Berdasarkan Harga (Price-Based Proxies)}

Set kesempatan berdasarkan harga merupakan proksi yang menyatakan bahwa prospek pertumbuhan perusahaan sebagian dinyatakan dalam harga pasar. Proksi ini didasari atas suatu ide yang menyatakan bahwa prosek pertumbuhan perusahaan secara parsial dinyatakan dalam harga-harga saham, dan perusahaan yang tumbuh akan memiliki nilai pasar yang lebih tinggi secara relatif untuk aktiva-aktiva yang dimiliki. Set kesempatan investasi yang didasari pada harga akan berbentuk suatu rasio sebagai suatu ukuran aktiva yang dimiliki dan nilai pasar perusahaan. Rasio-rasio yang telah digunakan yang berkaitan dengan proksi berdasarkan pasar antara lain Market to Book Value of Equity; Book to Market Value of Assets; Tobin's Q; Earning to Price Ratios; Ratio of Property, Plant and Equipment to Firm Value; Ratio of Depreciation to Firm Value; Market Value of Equity Plus Book Value of Debt; Dividend Yield; Return on Equity; Non-interest Revenue to Total Revenue.

\section{Proksi Berdasarkan Investasi (investment- based poxies)}

Ide proksi set kesempatan investasi berdasarkan investasi mengungkapkan bahwa suatu kegiatan investasi yang besar berkaitan secara positif dengan nilai set kesempatan investasi suatu perusahaan. Perusahaan-perusahaan yang memiliki suatu set kesempatan investasi yang tinggi seharusnya juga memiliki suatu tingkatan investasi yang tinggi pula dalam bentuk aktiva yang ditempatkan atau yang diinvestasikan untuk waktu yang lama dalam suatu perusahaan. Bentuk dari proksi ini adalah suatu rasio yang membandingkan suatu pengukuran investasi yang telah diinvestasikan dalam bentuk aktiva tetap atau suatu hasil operasi yang diproduksi dari aktiva yang telah diinvestasikan. Rasio-rasio yang telah digunakan yang berkaitan dengan proksi berdasarkan investasi tersebut antara lain the Ratio of $R \& D$ to Asset, the Ratio of $R \& D$ to sales, Ratio of Capital Expenditure to Firm value, Investment Intensity, Ratio of Capital to Book Value of Asset, Investment to Sales Ratio, Ratio of Capital Addition to Asset Book Value, Investment to Earning Ratio, Log of Firm Value.

\section{Proksi Berdasarkan Varian (Variance Measures)}

Proksi set kesempatan investasi berdasarkan varian mengungkapakan bahwa suatu opsi akan menjadi lebih bernilai jika menggunakan variabilitas ukuran untuk memperkirakan besarnya opsi yang tumbuh, seperti variabilitas return yang mendasari peningkatan aktiva. Ukuran yang berkaitan dengan proksi berdasarkan varian tersebut antara lain Variance of Return, Asset Beta, The Variance of Asset Deflated Sales.

\section{Proksi Gabungan dari Proksi Individual}

Alternatif proksi gabungan investasi dilakukan sebagai upaya untuk mengurangi measurement error yang ada pada proksi individual, sehingga akan menghasilkan pengukuran yang lebih baik untuk set kesempatan investasi. Metode yang dapat digunakan untuk menggabungkan beberapa proksi individual menjadi satu proksi yang akan diuji lebih lanjut adalah dengan menggunakan analisis faktor.

Menurut Darmadji dan Fackruddin (2001) dividen merupakan pembagian sisa laba bersih perusahaan yang didistribusikan kepada pemegang saham atas persetujuan RUPS (Rapat Umum Pemegang Saham). Dividen yang dibagikan dapat berupa dividen tunai/cash dividend (yang artinya setiap pemegang saham diberikan dividen berupa uang tunai dalam jumlah tertentu untuk setiap lembar saham) atau dapat dibagikan stock dividend kepada pemegang saham yang nantinya akan menambah jumlah saham yang dimilikinya. Kebijakan dividen adalah suatu keputusan perusahaan mengenai berapa besar cash dividend yang harus dibayarkan dan berapa kali dividen tersebut dibayarkan dalam satu tahun (Arifin 2005).

Hasil penelitian Yudianti (2003) dalam Wardani dan Siregar (2009) menyatakan bahwa aliran kas bebas positif berpengaruh positif terhadap nilai pemegang saham secara signifikan. Namun, aliran kas bebas negatif tidak berpengaruh signifikan terhadap nilai pemegang saham. Penelitian Wardani dan Siregar (2009) juga menyatakan bahwa aliran kas bebas berpengaruh positif signifikan terhadap nilai pemegang saham. Tujuan dari organisasi komersial adalah memaksimalkan nilai pemegang saham melalui dividen dan kenaikan harga saham. Aliran kas bebas yang tinggi mengindikasikan kinerja perusahaan yang tinggi. Aliran kas bebas yang tinggi juga menggambarkan akan adanya pertumbuhan penciptaan kas di masa depan. Kinerja perusahaan yang tinggi akan meningkatkan nilai pemegang saham yang diwujudkan dalam bentuk return yang lebih tinggi melalui dividen, harga saham, atau laba ditahan untuk diinvestasikan dimasa yang akan datang. Hipotesis dalam penelitian ini adalah: 
$\mathrm{H}_{1}$ : Aliran kas bebas berpengaruh secara positif terhadap nilai pemegang saham

Peningkatan pendanaan melalui utang merupakan salah satu alternatif untuk mengurangi biaya keagenan. Hutang dapat mengendalikan manajer untuk mengurangi tindakan perquisites dan kinerja perusahaan menjadi lebih efisien sehingga penilaian investor terhadap perusahaan akan meningkat.

Penelitian yang dilakukan De Angelo \& Masulis (1980); (Stulz 1990); McConnel dan Servaes (1995), Jung, Kim, Stulz (1996), Chen (2002) dalam Haruman (2008) serta Wijaya dkk. (2010) menyimpulkan bahwa financing berpengaruh positif terhadap nilai perusahaan. Hipotesis penelitian ini adalah:

$\mathrm{H}_{2}$ : Keputusan pendanaan berpengaruh secara positif terhadap nilai pemegang saham

Perusahaan yang mempunyai aliran kas bebas dengan set kesempatan investasi yang tinggi, maka manajernya akan menggunakan aliran kas bebas tersebut untuk membiayai proyek dengan nilai bersih sekarang positif sehingga akan meningkatkan nilai pemegang saham.

Penelitian yang dilakukan Subekti dan Kusuma (2001) serta Fijrijanti dan Hartono (2002) membuktikan kemampuan set kesempatan investasi dalam memprediksi pertumbuhan perusahaan yang berdampak terhadap nilai perusahaan dan nilai pemegang saham. Wardani dan Siregar (2009) menemukan bahwa aliran kas bebas berpengaruh positif terhadap nilai pemegang saham dimoderasi oleh set kesempatan investasi. Hipotesis penelitian ini adalah:

$\mathrm{H}_{3}$ : Set kesempatan investasi dapat memoderasi pengaruh positif aliran kas bebas terhadap nilai pemegang saham.

Jensen (1986) dalam Wardani dan Siregar (2009) memprediksi bahwa harga saham akan meningkat jika perusahaan membayar atau berjanji untuk membayar kelebihan kas yang dimiliki kepada pemegang saham. Dengan kata lain, peningkatan pembayaran dividen dalam bentuk dividen kas akan menghasilkan respon positif pada harga saham dalam jangka pendek.

Penelitian yang dilakukan Yudianti (2003) dalam Wardani dan Siregar (2009) menunjukkan bahwa perusahaan dengan tingkat pertumbuhan rendah dan aliran kas bebas tinggi, maka kenaikan pembayaran dividen akan berdampak positif terhadap hubungan aliran kas bebas dengan nilai pemegang saham karena kebijakan ini menunjukkan pengurangan kebijakan manajemen untuk investasi yang berlebih. Wardani dan
Siregar (2009) menemukan bahwa aliran kas bebas berpengaruh positif terhadap nilai pemegang saham dimoderasi oleh dividen. Maka hipotesis yang diajukan dalam penelitian ini adalah:

$\mathrm{H}_{4}$ : Dividen dapat memoderasi pengaruh positif aliran kas bebas terhadap nilai pemegang saham

Fama dan French (1998) dalam Wijaya dkk. (2010) menemukan bahwa investasi yang dihasilkan dari leverage memiliki informasi yang positif tentang perusahaan di masa yang akan datang, selanjutnya berdampak positif terhadap nilai perusahaan. Perusahaan yang mempunyai dana yang besar (berasal dari leverage) dengan set kesempatan investasi yang tinggi, maka manajernya akan menggunakan dana tersebut untuk membiayai proyek dengan nilai bersih sekarang positif sehingga akan meningkatkan nilai pemegang saham. Hipotesis penelitian ini adalah:

$\mathrm{H}_{5}$ : Set kesempatan investasi dapat memoderasi pengaruh positif keputusan pendanaan terhadap nilai pemegang saham

Penelitian yang dilakukan oleh Baskin (1989) dan Adedeji (1998) dalam Haruman (2008) menemukan bahwa financial leverage mempunyai pengaruh yang positif terhadap dividend payout ratio. Perusahaan dengan prospek yang baik, cenderung akan mempergunakan hutang sebagai alternatif untuk memenuhi kebutuhan pembayaran dividen dalam jangka pendek, apabila perusahaan tidak mempunyai dana internal untuk memenuhi dana tersebut. Sehingga jika perusahaan menggunakan hutang sebagai alternatif kebutuhan untuk pembayaran dividen maka nilai pemegang saham akan meningkat. Hipotesis dalam penelitian ini adalah:

$\mathrm{H}_{6}$ : Dividen dapat memoderasi pengaruh positif keputusan pendanaan terhadap nilai pemegang saham.

\section{METODE PENELITIAN}

Data penelitian ini berupa laporan keuangan publikasian tahunan yang telah diaudit, yang terdiri dari neraca, laba rugi dan laporan arus kas selama tahun 2005-2009. Laporan keuangan perusahaan diperoleh dari situs resmi BEI www.idx.co.id dan melalui Pojok Bursa Efek Indonesia Universitas Muhammadiyah Yogyakarta.

Teknik pengambilan sampel menggunakan metode purposive sampling yaitu pengambilan sampel berdasarkan pada kriteria tertentu yang dikehendaki peneliti. Kriteria sampel dalam penelitian ini adalah sebagai berikut: 1) per- 
usahaan yang masuk kategori manufaktur yang terdaftar di Bursa Efek Indonesia (BEI) dengan periode pengamatan 2005-2009, 2) perusahaan yang mempublikasikan laporan keuangan dengan menggunakan tahun buku yang berakhir pada tanggal 31 Desember, 3) perusahaan tidak memiliki saldo ekuitas negatif dan membagi dividen tunai setiap satu tahun selama periode pengamatan.

Penelitian ini menggunakan data sekunder, yaitu data yang diperoleh secara tidak langsung dari sumbernya. Pengumpulan data diperoleh dengan mengutip dari laporan keuangan perusahaan sampel dan ICMD (Indonesian Capital Market Directory). Data diperoleh dari dari situs resmi BEI www.idx.co.id dan melalui Pojok Bursa Efek Indonesia Universitas Muhammadiyah Yogyakarta.

\section{Definisi Operasional dan Pengukuran dan Pengukuran Variabel}

1. Nilai Pemegang Saham (Shareholder Value)

Nilai pemegang saham merupakan nilai perusahaan dikurangi dengan utang. Formula matematisnya adalah sebagai berikut:

$$
\mathrm{SHV}=\frac{\left(\text { OS }_{\text {it }} \times \text { HPS }_{\text {it }}\right)+\text { Ekuitas }}{\text { Total Aset }_{i t}}
$$

Keterangan:

SHV = Shareholder value

OS = Outstanding share

2. Aliran Kas Bebas (Free Cash Flow)

Aliran kas bebas merupakan kas perusahaan yang dapat didistribusikan kepada pemegang saham yang tidak digunakan untuk modal kerja atau investasi pada aset tetap. Aliran kas bebas dalam penelitian ini diukur dengan formula

$$
\mathrm{FCF}_{\mathrm{it}}=\frac{\mathrm{AKO}_{\mathrm{it}}-\mathrm{PM}_{\mathrm{it}}-\mathrm{NWC}_{\mathrm{it}}}{\text { Ekuitas }}
$$

Keterangan:

$\mathrm{FCF}=$ Free cash flow

AKO = Aliran kas operasi

PM = Pengeluaran modal

$\mathrm{NWC}=$ Net working capital

3. Keputusan Pendanaan

Keputusan pendanaan berkaitan dengan pemilihan sumber dana, baik berasal dari internal perusahaan maupun eksternal perusahaan. Keputusan pendanaan dalam penelitian ini diukur dengan formula:

$$
\text { DER }=\frac{\text { TotalHutang }}{\text { TotalEkuitas }}
$$

Keterangan:

DER = Debt to equity ratio
4. Set Kesempatan Investasi

Set kesempatan investasi merupakan tersedianya alternatif investasi di masa yang akan datang bagi perusahaan. Set kesempatan investasi perusahaan merupakan variabel yang tidak dapat diobservasi (variabel laten), sehingga diperlukan proksi (Hartono 1999). Peneliti menggunakan lima proksi tunggal yaitu:

a. Rasio market to book value of equity (MVEBVE)

MVEBVE $=$ Lembar Saham Beredar $\mathrm{x}$ Harga Penutupan Saham : Total Ekuitas

b. Rasio Market to Book Value of Assets (MVABVA)

MVABVA $=$ Total Aset - Total Ekuitas + (Lembar Saham beredar $\mathrm{x}$ harga Penutupan Saham) : Total Aset

c. Rasio firm value to book value of PPE (VPPE)

VPPE $=$ Total Aset - Total Ekuitas + (Lembar Saham Beredar $\mathrm{x}$ Harga Penutupan Saham) : Aktiva Tetap Net

d. Capital Addition to Assets Book Value Ratio (CEBVA)

CEBVA $=($ Nilai Buku Aktiva Tetap $\mathrm{t}-$ Nilai Buku Aktiva Tetap t-1) : Total Aset

e. Capital Addition to Assets Market Value Ratio (CEMVA)

CEMVA $=($ Nilai Buku Aktiva Tetap $\mathrm{t}-$ Nilai Buku Aktiva Tetap t-1) : (Total Aset - Total Ekuitas) + (Jumlah Saham Beredar $\mathrm{x}$ Closing Proce)

\section{Dividen}

Dividen menunjukkan seberapa besar laba perusahaan dibagikan kepada pemegang saham. Variabel ini diukur dengan Dividend Yield

$$
\mathrm{DY}=\frac{\mathrm{DPS}_{\mathrm{it}}}{\mathrm{HPS}_{\mathrm{it}}}
$$

Keterangan:

DY = Dividend yield

DPS $=$ Dividend per share

HPS $=$ Harga penutupan saham

6. Ukuran Perusahaan

Ukuran perusahaan menggambarkan besar kecilnya suatu perusahaan yang ditujukan oleh total aktiva, jumlah penjualan, rata-rata tingkat penjualan dan rata-rata aktiva. Variabel ini diukur dengan formula sebagai berikut: $\mathrm{SIZE}=\ln$ total asset 


\section{HASIL PENELITIAN DAN PEMBAHASAN}

Analisis data dalam penelitian ini menggunakan sampel sebanyak 23 perusahaan yang dipilih dengan metode purposive sampling dengan kriteria yang ditetapkan. Ringkasan proses pemilihan sampel disajikan pada Tabel 1.

Tabel 1. Proses Pemilihan Sampel

\begin{tabular}{lc}
\hline Uraian & Jumlah \\
\hline $\begin{array}{l}\text { Perusahaan manufaktur terdaftar di BEI } \\
\text { selama tahun 2005 sampai 2009 }\end{array}$ & 146 \\
$\begin{array}{l}\text { Perusahaan tidak mempublikasikan } \\
\text { laporan keuangan menggunakan tahun } \\
\text { buku yang berakhir pada 31 Desember } \\
\text { dan menggunakan mata uang selain }\end{array}$ & $(2)$ \\
Rupiah & \\
Perusahaan yang memiliki ekuitas \\
negatif dan tidak membayarkan d \\
$\begin{array}{l}\text { Emiten yang memenuhi kriteria } \\
\text { purposive sampling }\end{array}$
\end{tabular}

\section{Analisis Faktor}

Variabel investment opportunity set (IOS) dalam penelitian ini diproksi menggunakan lima variabel asli, yaitu: rasio market to book value of equity (MVEBVE), market value to book value of asset (MVABVA), firm value to book value of PPE (VPPE), capital addition to assets book value ratio (CEBVA) dan capital addition to assets market value ratio (CEMVA).

Hasil analisis factor diperoleh nilai KMOMSA sebesar 0,542, sehingga kelima variabel tersebut dapat dilakukan analisis mencari factor. Tabel 2 menunjukkan nilai communalities individual dari IOS. Nilai tersebut digunakan untuk menentukan jumlah faktor representasi dari variabel-variabel aslinya. Jumlah nilai communalities proksi individual set kesempatan investasi adalah 4,083. Untuk mencapai nilai tersebut diperlukan dua komponen faktor yang memiliki eigenvalues di atas satu, yaitu faktor satu sebesar 2,279 dan factor 2 sebesar 1,804. Hal ini sejalan dengan the rule of thumb bahwa jumlah faktor yang digunakan sebagai representasi adalah sebanyak faktor yang mempunyai nilai eigenvalues sama dengan atau lebih dari satu (Hair dkk. 1998 dalam Wardani dan Siregar 2009).

Tabel 2. Analisis Faktor Set Kesempatan Investasi

\begin{tabular}{lccccc}
\hline A. Commu- & MVEBVE MVABVA & VPPE & CEBVA CEMVA \\
nalities & 0,924 & 0,909 & 0,455 & 0,923 & 0,873 \\
\hline B. Eigenvalues & 1 & 2 & 3 & 4 & 5 \\
& 2,279 & 1,804 & 0,690 & 0,147 & 0,079 \\
\hline C. Korelasi & MVEBVE MVABVA & VPPE & CEBVA & CEMVA \\
Faktor 1 & 0,828 & 0,807 & 0,673 & $-0,415$ & $-0,562$ \\
Faktor 2 & 0,487 & 0,507 & $-0,050$ & 0,866 & 0,746 \\
\hline
\end{tabular}

Dalam penelitian ini terdapat dua faktor yang cukup menjelaskan hubungan timbal balik antara proksi set kesempatan investasi. Faktor satu adalah indeks umum set kesempatan investasi berbasis harga, yaitu MVABVA (skor=0,924), MVEBVE (skor=0,909) dan VPPE (skor=0,455). Sedangkan faktor dua indeks umum set kesempatan investasi berbasis investasi, yaitu CAPBVA (skor=0,923) dan CAPMVA (skor=0,873). Penentuan nilai proksi gabungan dari variable set kesempatan investasi didasarkan penjumlahan kedua faktor, yaitu faktor 1 (fact_1) dan faktor 2 (fact_2) menjadi fact_sum.

Statistik deskriptif variabel-variabel penelitian selama periode pengamatan disajikan pada Tabel 3 yang menunjukkan rata-rata aliran kas bebas (FCF) sebesar -0,09136 dengan deviasi standar 0,490377. Keputusan pendanaan (DER) memiliki rata-rata sebesar 1,20418 dengan deviasi standar 0,975249. Set kesempatan investasi (IOS) memiliki rata-rata sebesar -0,00002 dengan deviasi standar 1,414194. Dividen yield (DY) memiliki rata-rata sebesar 0,06040 dengan deviasi standar 0,117712 . Ukuran perusahaan (SIZE) memiliki rata-rata sebesar 14,32413 dengan standar deviasi 1,414984. Nilai pemegang saham (SHV) memiliki rata-rata sebesar 0,44044 dengan deviasi standar 1,364218 .

Tabel 3. Statistik Deskriptif

\begin{tabular}{lcccc}
\hline Variabel & Minimum & Maximum & Mean & Std. Deviasi \\
\hline FCF & $-0,998$ & 0,936 & $-0,09136$ & 0,490377 \\
DER & 0,000 & 6,068 & 1,20418 & 0,975249 \\
IOS & $-2,988$ & 3,675 & $-0,00002$ & 1,414194 \\
DY & 0,001 & 1,069 & 0,06040 & 0,117712 \\
SIZE & 11,587 & 18,457 & 14,32413 & 1,414984 \\
SHV & $-0,587$ & 5,524 & 0,44044 & 1,364218 \\
\hline
\end{tabular}

\section{Uji Asumsi Klasik}

1. Uji Normalitas

Hasil uji normalitas dengan metode uji OneSample Kolmogorov-Smirnov disajikan pada Tabel 4 yang menunjukkan nilai $p$-value dari KSZ unstandardized residual pada persamaan regresi sebesar 0,001 lebih kecil dari $\alpha=0.05$, maka dapat disimpulkan data tidak berdistribusi normal sehingga perlu dilakukan penghilangan outlier.

Hasil uji normalitas setelah dilakukan penghilangan outlier disajikan pada Tabel 5 yang menunjukkan nilai p-value dari KSZ unstandardized residual pada persamaan regresi sebesar 0,182 lebih besar dari $\alpha=0.05$, maka dapat disimpulkan data berdistribusi normal. 
Tabel 4. Uji Normalitas

\begin{tabular}{cccl}
\hline & $\mathbf{Z}$ & p-value & Keterangan \\
\hline One Sample KS & 1,957 & 0,001 & $\begin{array}{l}\text { Data tidak } \\
\text { berdistribusi normal }\end{array}$ \\
\hline
\end{tabular}

Tabel 5. Uji Normalitas Setelah Penghilangan Data Outlier

\begin{tabular}{cccl}
\hline & $\mathbf{Z}$ & p-value & Keterangan \\
\hline One Sample KS & 1,094 & 0,182 & $\begin{array}{l}\text { Data } \\
\text { berdistribusi normal }\end{array}$
\end{tabular}

2. Uji Multikolinearitas

Hasil uji multikolinearitas menggunakan metode variance inflation factor (VIF) disajikan pada Tabel 6 yang menunjukkan hasil perhitungan nilai tolerance menunjukkan tidak ada variabel bebas yang memiliki nilai tolerance kurang dari 0,1. Hasil perhitungan nilai variance inflation factor (VIF) menunjukkan tidak ada satu variabel bebas memiliki nilai VIF lebih dari 10. Jadi dapat disimpulkan bahwa tidak ada multikolinearitas antar variabel bebas dalam model regresi.

3. Uji Heteroskedastisitas

Hasil uji heteroskedastisitas menggunakan uji Glejser disajikan pada Tabel 7 yang menunjukkan bahwa tidak ada satupun variabel bebas yang signifikan secara statistis mempengaruhi variabel terikat nilai $\mathrm{ABS}$ e, hal ini terlihat dari nilai Sig. $t>0,05$. Jadi dapat disimpulkan model regresi tidak menunjukkan adanya heteroskedastisitas.

Tabel 6. Hasil Uji Multikolinearitas

\begin{tabular}{|c|c|c|c|}
\hline \multirow{2}{*}{$\begin{array}{c}\text { Variabel } \\
\text { Bebas }\end{array}$} & \multicolumn{2}{|c|}{ Collinearity Statistics } & \multirow[t]{2}{*}{ Kesimpulan } \\
\hline & Tolerance & VIF & \\
\hline FCF & 0,929 & 1,077 & $\begin{array}{l}\text { Tidak ada } \\
\text { multikolinearitas }\end{array}$ \\
\hline DER & 0,836 & 1,196 & $\begin{array}{l}\text { Tidak ada } \\
\text { multikolinearitas }\end{array}$ \\
\hline IOS & 0,789 & 1,267 & $\begin{array}{l}\text { Tidak ada } \\
\text { multikolinearitas }\end{array}$ \\
\hline DY & 0,865 & 1,156 & $\begin{array}{l}\text { Tidak ada } \\
\text { multikolinearitas }\end{array}$ \\
\hline SIZE & 0,870 & 1,149 & $\begin{array}{l}\text { Tidak ada } \\
\text { multikolinearitas }\end{array}$ \\
\hline
\end{tabular}

Tabel 7. Uji Heteroskedastisitas

\begin{tabular}{clcc}
\hline $\begin{array}{c}\text { Variabel } \\
\text { Terikat }\end{array}$ & $\begin{array}{c}\text { Variabel } \\
\text { bebas }\end{array}$ & Sig.t & Keterangan \\
\hline ABS e & FCF & 0,839 & Tdk terjadi heteroskedastisitas \\
& DER & 0,109 & Tdk terjadi heteroskedastisitas \\
& IOS & 0,640 & Tdk terjadi heteroskedastisitas \\
& DY & 0,800 & Tdk terjadi heteroskedastisitas \\
& SIZE & 0,118 & Tdk terjadi heteroskedastisitas \\
\hline
\end{tabular}

4. Hasil uji autokorelasi dilakukan dengan uji Durbin Watson statistics disajikan pada Tabel 8 menunjukkan bahwa nilai DW-test sebesar 2,178 berada pada daerah $\mathrm{dU}<\mathrm{DW}<4$-dU, artinya tidak ada autokorelasi negatif maupun positif.

Tabel 8. Uji Autokorelasi

\begin{tabular}{lccc}
\hline & DW & dU & 4-dU Keterangan \\
\hline $\begin{array}{l}\text { Durbin- } \\
\text { Watson }\end{array}$ & 2,178 & 1,780 & $\begin{array}{l}2,220 \\
\text { Tidak terdapat masalah } \\
\text { autokorelasi }\end{array}$ \\
\hline
\end{tabular}

\section{Pengujian Hipotesis}

Pengujian hipotesis satu sampai enam dalam penelitian ini menggunakan moderated regression analysis (MRA) atau uji interaksi. Hasil perhitungan MRA disajikan pada Tabel 9.

Hasil perhitungan pada Tabel 9 diperoleh persamaan sebagai berikut:

$$
\begin{aligned}
\mathrm{SHV}= & -0,380-0,081 \mathrm{FCF}+0,148 \mathrm{IOS}+0,058 \\
& \text { FCF } * \mathrm{IOS}+1,051 \quad \mathrm{FCF} \text { DY }+0,021 \\
& \text { DER }{ }^{*} \mathrm{IOS}+\varepsilon
\end{aligned}
$$

Tabel 9. Hasil Perhitungan Moderated Regression Analisys

\begin{tabular}{lrrl}
\hline \multicolumn{1}{c}{ Variabel } & B & \multicolumn{1}{c}{$\begin{array}{c}\text { Prob } \\
\text { (t-stat) }\end{array}$} & Keterangan \\
\hline Konstanta & $-0,380$ & 0,017 & \\
FCF & $-0,081$ & 0,028 & Signifikan \\
DER & $-0,020$ & 0,424 & Tdk signifikan \\
IOS & 0,148 & 0,000 & Signifikan \\
DY & $-0,538$ & 0,143 & Tdk signifikan \\
FCF*IOS & 0,058 & 0,006 & Signifikan \\
FCF*DY & 1,051 & 0,007 & Signifikan \\
DER*IOS & 0,021 & 0,017 & Signifikan \\
DER*DY & 0,357 & 0,209 & Tdk signifikan \\
SIZE & 0,017 & 0,103 & Tdk signifikan \\
\hline Adjusted R & 0,848 & & \\
F Statistic & 54,923 & & \\
Prob (F-stat) & 0,000 & & \\
\hline
\end{tabular}

1. Uji Signifikansi Nilai t

a. Pengujian hipotesis satu $\left(\mathrm{H}_{1}\right)$

Variabel aliran kas bebas (FCF) memiliki koefisien negatif -0,081 dengan $p$-value (sig) $0,028<\alpha(0,05)$, berarti aliran kas bebas berpengaruh negatif dan signifikan terhadap nilai pemegang saham. Hipotesis satu $\left(\mathrm{H}_{1}\right)$ dalam penelitian ini ditolak.

b. Pengujian hipotesis dua $\left(\mathrm{H}_{2}\right)$

Variabel keputusan pendanaan (DER) memiliki koefisien regresi sebesar -0,020 dengan $p$-value (sig) $0,424>\alpha(0,05)$, berarti keputusan pendanaan tidak berpengaruh signifikan terhadap kebijakan nilai pemegang saham. Hipotesis dua $\left(\mathrm{H}_{2}\right)$ dalam penelitian ini ditolak. 
c. Pengujian hipotesis tiga $\left(\mathrm{H}_{3}\right)$

Variabel moderat (FCF*IOS) memiliki koefisien regresi sebesar 0,058 dengan $p$ value $(0,006)<\alpha(0,05)$. Hal ini menunjukkan bahwa set kesempatan investasi dapat memoderasi pengaruh positif aliran kas bebas terhadap nilai pemegang saham. Hipotesis tiga $\left(\mathrm{H}_{3}\right)$ dalam penelitian ini diterima.

d. Pengujian hipotesis empat $\left(\mathrm{H}_{4}\right)$

Variabel moderat (FCF*DY) memiliki koefisien regresi sebesar 1,051 dengan $p$ value $(0,007)<\alpha(0,05)$. Hal ini menunjukkan bahwa dividen dapat memoderasi pengaruh positif aliran kas bebas terhadap nilai pemegang saham. Hipotesis keempat $\left(\mathrm{H}_{4}\right)$ dalam penelitian ini diterima.

e. Pengujian hipotesis lima $\left(\mathrm{H}_{5}\right)$

Variabel moderat (DER*IOS) memiliki koefisien regresi sebesar 0,021 dengan $p$ value $(0,017)<\alpha(0,05)$. Hal ini menunjukkan bahwa set kesempatan investasi dapat memoderasi pengaruh positif keputusan pendanaan terhadap nilai pemegang saham. Hipotesis kelima $\left(\mathrm{H}_{5}\right)$ dalam penelitian ini diterima.

f. Pengujian hipotesis enam $\left(\mathrm{H}_{6}\right)$

Variabel moderat (DER*DY) memiliki koefisien regresi sebesar 0,357 dengan $p$ value $(0,209)>\alpha(0,05)$. Hal ini menunjukkan bahwa dividen bukan merupakan variabel pemoderasi yang dapat menginteraksi hubungan antara keputusan pendanaan dengan nilai pemegang saham. Hipotesis keenam $\left(\mathrm{H}_{6}\right)$ dalam penelitian ini ditolak.

g. Pengujian variabel kontrol SIZE

Variabel ukuran perusahaan (SIZE) memiliki koefisien regresi sebesar 0,017 dengan $p$ value (sig) $0,103>\alpha(0,05)$, berarti ukuran perusahaan tidak berpengaruh signifikan terhadap nilai pemegang saham.

2. Uji Signifikansi Nilai F

Hasil pengujian pada Tabel 4.9 diperoleh $p$ value (sig) $\mathrm{F}$ sebesar $0,000<\alpha(0,05)$, berarti aliran kas bebas, keputusan pendanaan, set kesempatan investasi, dividen, moderasi aliran kas bebas dengan set kesempatan investasi, moderasi aliran kas bebas dengan dividen, moderasi keputusan pendanaan dengan set kesempatan investasi, moderasi keputusan pendanaan dengan dividen dan ukuran perusahaan secara bersama-sama berpengaruh signifikan terhadap nilai pemegang saham.

3. Koefisien Determinasi (Adjusted R-square)

Nilai adjusted $R$ square sebesar 0,848 menunjukkan bahwa $84,8 \%$ variasi nilai pemegang saham dapat dijelaskan oleh faktor- faktor aliran kas bebas, keputusan pendanaan, set kesempatan investasi, dividen, moderasi aliran kas bebas dengan set kesempatan investasi, moderasi aliran kas bebas dengan dividen, moderasi keputusan pendanaan dengan set kesempatan investasi, moderasi keputusan pendanaan dengan dividen dan ukuran perusahaan. Sedangkan sisanya sebesar 15,2\% dijelaskan oleh variabel bebas lainnya yang tidak diamati dalam penelitian ini.

Hasil pengujian pengujian hipotesis satu menunjukkan aliran kas bebas berpengaruh negatif dan signifikan terhadap nilai pemegang saham. Secara teori aliran kas bebas yang tinggi mengindikasikan kinerja perusahaan yang tinggi sehingga nilai perusahaan akan meningkat. Pengaruh negatif aliran kas bebas terhadap nilai pemegang saham dalam penelitian ini disebabkan adanya kekhawatiran dari pemegang saham bahwa aliran kas bebas yang ada di perusahaan akan digunakan oleh manajemen untuk melakukan tindakan opportunistic guna memperkaya diri sendiri. Hasil penelitian ini berbeda dengan Yudianti (2003) dalam Wardani dan Siregar (2009) serta Wardani dan Siregar (2009) yang menyimpulkan adanya pengaruh positif aliran kas bebas terhadap nilai pemegang saham.

Pengujian hipotesis dua menunjukkan keputusan pendanaan tidak berpengaruh signifykan terhadap nilai pemegang saham. Secara teori hutang akan mengendalikan manajer untuk mengurangi tindakan perquisites dan kinerja perusahaan menjadi lebih efisien sehingga penilaian investor terhadap perusahaan akan meningkat. Hasil yang tidak signifikan dalam penelitian ini disebabkan adanya kekhawatiran dari investor bahwa peningkatan hutang akan menyebabkan perusahaan mengalami debt default dan meningkatkan resiko kebangkrutan.

Pengujian hipotesis tiga menunjukkan set kesempatan investasi dapat memoderasi pengaruh positif aliran kas bebas terhadap nilai pemegang saham. Perusahaan yang mempunyai aliran kas bebas dengan set kesempatan investasi yang tinggi, maka manajernya akan menggunakan aliran kas bebas tersebut untuk membiayai proyek dengan nilai bersih sekarang positif sehingga akan meningkatkan nilai pemegang saham. Hasil penelitian ini sesuai dengan Wardani dan Siregar (2009) yang menemukan bahwa aliran kas bebas berpengaruh positif terhadap nilai perusahaan dimoderasi oleh set kesempatan investasi.

Pengujian hipotesis empat menunjukkan dividen dapat memoderasi pengaruh positif aliran kas bebas terhadap nilai pemegang saham. 
Perusahaan dengan tingkat pertumbuhan rendah dan aliran kas bebas tinggi, maka kenaikan pembayaran dividen akan berdampak positif terhadap hubungan aliran kas bebas dengan nilai pemegang saham karena kebijakan ini menunjukkan pengurangan kebijakan manajemen untuk investasi yang berlebihan. Hasil penelitian ini sesuai dengan Wardani dan Siregar (2009) yang menemukan bahwa aliran kas bebas berpengaruh positif terhadap nilai perusahaan dimoderasi oleh dividen.

Pengujian hipotesis lima menunjukkan set kesempatan investasi dapat memoderasi pengaruh positif keputusan pendanaan terhadap nilai pemegang saham. Perusahaan yang mempunyai dana yang besar (berasal dari leverage) dengan set kesempatan investasi yang tinggi, maka manajernya akan menggunakan dana tersebut untuk membiayai proyek dengan nilai bersih sekarang positif sehingga akan meningkatkan nilai pemegang saham. Hasil penelitian ini sesuai dengan Fama dan French (1998) dalam (Wijaya dkk. 2010) yang menemukan bahwa investasi yang dihasilkan dari leverage memiliki informasi yang positif tentang perusahaan di masa yang akan datang, selanjutnya berdampak positif terhadap nilai perusahaan.

Pengujian hipotesis enam menunjukkan dividen bukan merupakan variabel pemoderasi yang dapat menginteraksi hubungan antara keputusan pendanaan dengan nilai pemegang saham. Secara teori perusahaan dengan prospek yang baik, cenderung akan mempergunakan hutang sebagai alternatif untuk memenuhi kebutuhan pembayaran dividen dalam jangka pendek, apabila perusahaan tidak mempunyai dana internal untuk memenuhi dana tersebut guna meningkatkan nilai pemegang saham. Hasil yang tidak signifikan disebabkan perusahaan lebih memilih menggunakan hutang untuk meningkatkan investasi dan ekspansi usaha yang akan menaikkan nilai perusahaan dan juga harga sahamnya.

\section{KESIMPULAN}

Berdasarkan hasil analisis yang telah dilakukan dapat diambil kesimpulan sebagai berikut: 1) aliran kas bebas berpengaruh negatif terhadap nilai pemegang saham, 2) keputusan pendanaan tidak berpengaruh signifikan terhadap nilai pemegang saham, 3) set kesempatan investasi dapat memoderasi pengaruh positif aliran kas bebas terhadap nilai pemegang saham, 4) dividen dapat memoderasi pengaruh positif aliran kas bebas terhadap nilai pemegang saham, 5) set kesempatan investasi dapat memoderasi pengaruh positif keputusan pendanaan terhadap nilai pemegang saham, 6) dividen bukan merupakan variabel pemoderasi yang dapat menginteraksi hubungan antara keputusan pendanaan dengan nilai pemegang saham.

Berdasarkan hasil analisis pembahasan serta beberapa kesimpulan tersebut maka penulis memberikan saran sebagai berikut: 1) investor dan calon investor di pasar modal perlu memperhatikan besar kecilnya free cash flow, set kesempatan investasi dan dividen karena variabel-variabel ini berpengaruh terhadap nilai pemegang saham, 2) proksi IOS hendaknya ditambah dengan proksi yang berbasis variance, 3) memperpanjang periode pengamatan sehingga dapat menggambarkan kondisi yang sebenarnya.

Keterbatasan dalam penelitian ini sebagai berikut: 1) proksi IOS dalam penelitian ini hanya menggunakan 4 variabel yang berbasis harga dan investasi, yaitu: market to book value of equity (MVEBVE), market value to book value of asset (MVABVA), firm value to book value of PPE (VPPE), capital addition to assets book value ratio (CEBVA) dan capital addition to assets market value ratio (CEMVA), 2) periode pengamatan relatif pendek, yaitu lima tahun sehingga hasilnya kurang valid.

\section{DAFTAR PUSTAKA}

Arifin, Zaenal. 2005. Teori Keuangan dan Pasar Modal. Yogyakarta. Ekonisia.

Darmadji, Tjiptono dan Fackruddin, Hendy M. 2001. Pasar Modal di Indonesia. Jakarta. Salemba Empat.

Faisal, Muhamad. 2004. Analisis Pengaruh Free Cash Flow, Set Kesempatan Investasi, Kepemilikan Manajerial dan Ukuran Perusahaan Terhadap Kebijakan Hutang (Studi Empiris Pada Perusahaan-Perusahaan Sektor Industri Pemanufakturan di Bursa Efek Jakarta). Tesis. UNDIP. Semarang.

Fauz, Achmad dan Rosidi. 2007. "Pengaruh Aliran Kas Bebas, Kepemilikan Manajerial, Kepemilikan Institusional, Kebijakan Utang dan Colleteral Asset terhadap Kebijakan Dividen. Jurnal Ekonomi dan Manajemen". Volume 8, Nomor 2, Juni, hal. 259-267.

Fijrijanti, Tetet dan Hartono, Jogiyanto. 2002. "Set Kesempatan Investasi: Konstruksi Proksi dan Analisi Hubungannya dengan Kebijakan Pendanaan dan Deviden". Jurnal Riset Akuntansi Indonesia. Vol . 5. No. 1. hal. 35-63. 
Haruman, Tendi. 2008. "Pengaruh Struktur Kepemilikan Terhadap Keputusan Keuangan dan Nilai Perusahaan: Studi Pada Perusahaan Manufaktur di PT. Bursa Efek Indonesia”. Makalah Simposium Nasional Akuntansi 11. Pontianak.

Norpawitri, V.M.Agustina. 2005. “Analisis Korelasi Investment Opportunity Set Terhadap Return Saham (Pada Saat Pelaporan Keuangan Perusahaan)”. Jurnal Akuntansi \& Manajemen. hal. 1-28.

Tarjo dan Jogiyanto. 2005. "Analisa Free Cash Flow Dan Kepemilikan Manajerial Terhadap Kebijakan Utang Pada Perusahaan Publik Di Indonesia”. Makalah Simposium Nasional Akuntansi VI. Surabaya 16-17 Oktober. hal. 278-295.
Wahidawati. 2002. "Pengaruh Kepemilikan Manajerial dan Kepemilikan Institusional pada Kebijakan Hutang Perusahaan: Sebuah Perspektif Theory Agency”. Jurnal Riset Akuntansi Indonesia, Vol. 5, No. 1, hal 1-16.

Wardani, R.A.Kusuma dan Siregar, Baldric, 2009. "Pengaruh Aliran Kas Bebas Terhadap Nilai Pemegang Saham Dengan Set Kesempatan Investasi dan Dividen Sebagai Variabel Moderator". Jurnal Akuntansi dan Manajemen. Vol. 20. No. 3 Desember, hal. 157-174.

Wijaya, L.R. Puspo, Bandi dan Wibawa, Anas. 2010. "Pengaruh Keputusan Investasi, Keputusan Pendanaan, Dan Kebijakan Dividen Terhadap Nilai Perusahaan”. Makalah Simposium Nasional Akuntansi XIII. Purwokerto. hal. 1-21. 